Article

\title{
Screening of Satureja subspicata Vis. Honey by HPLC-DAD, GC-FID/MS and UV/VIS: Prephenate Derivatives as Biomarkers
}

\author{
Igor Jerković ${ }^{1, *}$, Marina Kranjac ${ }^{1}$, Zvonimir Marijanović ${ }^{2}$, Marina Zekić ${ }^{1}$, Ani Radonić ${ }^{1}$ \\ and Carlo Ignazio Giovanni Tuberoso ${ }^{3}$ \\ 1 Department of Organic Chemistry, Faculty of Chemistry and Technology, University of Split, \\ Ruđera Boškovića 35, Split 21000, Croatia; mkranjac@ktf-split.hr (M.K.); zekic@ktf-split.hr (M.Z.); \\ radonic@ktf-split.hr (A.R.) \\ 2 Department of Food Technology, Marko Marulić Polytechnic in Knin, Petra Krešimira IV 30, Knin 22300, \\ Croatia; zmarijanovic@veleknin.hr \\ 3 Department of Life and Environmental Sciences, University of Cagliari, via Ospedale 72, Cagliari 09124, \\ Italy; tuberoso@unica.it \\ * Correspondence: igor@ktf-split.hr; Tel.: +385-21-329-422; Fax: +385-21-329-461
}

Academic Editor: Luca Forti

Received: 27 February 2016 ; Accepted: 15 March 2016 ; Published: 21 March 2016

\begin{abstract}
The samples of Satureja subspicata Vis. honey were confirmed to be unifloral by melissopalynological analysis with the characteristic pollen share from $36 \%$ to $71 \%$. Bioprospecting of the samples was performed by HPLC-DAD, GC-FID/MS, and UV/VIS. Prephenate derivatives were shown to be dominant by the HPLC-DAD analysis, particularly phenylalanine $(167.8 \mathrm{mg} / \mathrm{kg})$ and methyl syringate (MSYR, $114.1 \mathrm{mg} / \mathrm{kg}$ ), followed by tyrosine and benzoic acid. Higher amounts of MSYR (3-4 times) can be pointed out for distinguishing S. subspicata Vis. honey from other Satureja spp. honey types. GC-FID/MS analysis of ultrasonic solvent extracts of the samples revealed MSYR (46.68\%, solvent pentane/ $\mathrm{Et}_{2} \mathrm{O} 1: 2(v / v) ; 52.98 \%$, solvent $\left.\mathrm{CH}_{2} \mathrm{Cl}_{2}\right)$ and minor abundance of other volatile prephenate derivatives, as well as higher aliphatic compounds characteristic of the comb environment. Two combined extracts (according to the solvents) of all samples were evaluated for their antioxidant properties by FRAP and DPPH assay; the combined extracts demonstrated higher activity (at lower concentrations) in comparison with the average honey sample. UV/VIS analysis of the samples was applied for determination of CIE Lab colour coordinates, total phenolics (425.38 mg GAE $/ \mathrm{kg}$ ), and antioxidant properties $\left(4.26 \mathrm{mmol} \mathrm{Fe}{ }^{2+} / \mathrm{kg}\right.$ (FRAP assay) and $0.8 \mathrm{mmol} \mathrm{TEAC} / \mathrm{kg}$ (DDPH assay)).
\end{abstract}

Keywords: Satureja subspicata Vis. honey; GC-FID/MS; HPLC-DAD; UV/Vis spectrometry; prephenate derivatives; methyl syringate

\section{Introduction}

It has been pointed out that targeted analysis of honey's natural organic compounds could be a useful tool for characterization of its botanical origin accompanying melissoplaynological analysis and other routine physical-chemical parameters [1-3]. A large biodiversity of natural organic compounds derived from different biosynthetic pathways has been found in honey [1]: carbohydrates, nitrogen containing compounds, phenolics, volatiles (e.g., monoterpenes, norisoprenoids or benzene derivatives), and others. The honey compounds have been found to be the plant-derived constituents (phytochemicals) in their native form or transformed by the bees, the compounds generated by the bees or transferred from the combs, but also the products of thermal treatment and/or prolonged storage (derived from Maillard reactions and Strecker degradations) as well as microbial or environmental 
contaminants. Our recent research has been focused on the bioprospecting of different honey types in order to characterize the samples by screening the organic compounds to find characteristic chemical profiles, chemical biomarkers of the honey botanical origin, or bioactive compounds [4-6].

The genus Satureja is comprised of $c a .200$ species, and in Croatian flora, four species are distributed in Mediterranean region: S. montana L., S. cuneifolia Ten., S. subspicata Vis., and an endemic S. visianii Šilić [7-9]. Due to the presence of secondary metabolites such as flavonoids, steroids, essential oils, or tannins, Satureja species have been known for their healing properties and have been used as traditional folk remedies [9] with antimicrobial activity, anti-inflammatory, and anti-nociceptive effects $[10,11]$. Rutin, quercetin, caffeic, $p$-coumaric, ellagic, protocatechuic, rosmarinic, and syringic acids were identified and quantified in S. subspicata Vis. of Croatian origin using HPLC-DAD [12]. The results showed that its extracts contain polyphenolics and other antioxidant compounds with chelating and radical scavenging properties. Carvacrol, $\alpha$-pinene, $p$-cymene, $\gamma$-terpinene, and thymol methyl ether appeared as the major components of the essential oil of $S$. subspicata Vis., followed by smaller percentages of myrcene, linalool, $\beta$-caryophyllene, limonene, geranyl acetate, oct-1-en-3-ol, nerol, thymol, and borneol [9]. Satureja species are also nectariferous plants. Our previous research has been focused on S. montana L. and S. hortensis L. honey types [13,14]. However, S. subspicata Vis. honey has not yet been investigated. Therefore, the objectives of the present bioprospecting study (which is a first time report, to our best knowledge) were: (i) targeted HPLC-DAD analyses of native unifloral S. subspicata Vis. honey samples focused on characteristic non-volatiles; (ii) GC-FID/MS analyses of the ultrasonic solvent extracts of the samples directed toward volatile/semi-volatile organic compounds and evaluation of their 2,2-diphenyl-1-picrylhydrazyl (DPPH) radical scavenging ability and ferric reduction activity potential (FRAP); (iii) UV/VIS determination of colour, total phenolic content, and antioxidant properties (DPPH and FRAP assays) of the samples; (iv) the comparison of the obtained results with our other reports on different Satureja spp. honey types or other honeys of different botanical origin.

\section{Results and Discussion}

All the samples of $S$. subspicata Vis. honey were unifloral according to the melissopalynological analysis, with Satureja subspicata Vis. pollen share in the range from $36 \%$ to $71 \%$. Accompanying plant species were also determined: Centaurea jacea L. (2\%-19\%), Rhamnus spp. (0\%-19\%), Apiaceae $(0 \%-13 \%)$, Fabaceae $(0 \%-7 \%)$, Melilotus spp. (0\%-6\%), Trifolium spp. $(0 \%-4 \%)$, Asteraceae $(0 \%-3 \%)$, Centaurea cyanus L. (0\%-2\%), Eryngium spp. (0\%-2\%), Brassicaceae $(0 \%-2 \%)$, Scabiosa spp. $(0 \%-2 \%)$, and Liliaceae $(0 \%-2 \%)$. The samples were directly analysed by HPLC-DAD and UV/VIS, while the obtained ultrasonic solvent extracts were analysed by GC-FID/MS and two combined extracts (according to the solvents) of all samples by UV/VIS (for research of their antioxidant properties).

\subsection{HPLC-DAD Analysis of Native Honey Samples}

The compounds identified in Satureja subspicata Vis. native honey samples by targeted HPLC analysis are presented in Table 1. Prephenate derivatives dominated (particularly phenylalanine, methyl syringate, tyrosine, and benzoic acid). Methyl syringate (MSYR) was found at high amounts $(114.1 \pm 17.8 \mathrm{mg} / \mathrm{kg})$. It was highlighted in our previous papers $[13,14]$ as non-specific chemical marker of different Satureja honeys $(27.98 \pm 12.95 \mathrm{mg} / \mathrm{kg}$ of Satureja montana L. honey samples and $39.32 \mathrm{mg} / \mathrm{kg}$ of Satureja hortensis L. honey sample). However, the 3-4 times higher amount of MSYR found in this present research can be pointed out for distinguishing S. subspicata Vis. honey from other Satureja spp. honeys. A twofold higher quantity of MSYR $(229.2 \pm 57.9 \mathrm{mg} / \mathrm{kg})$ was found in Asphodel monofloral honey [15] and indicated that the chemical marker originated from the nectar (with an average contribution of the nectar to the honey of $80 \%$ ). MSYR was also detected in manuka honey [16] at higher levels (45 mg/kg). Lower MSYR levels (0.093 to $5.044 \mathrm{mg} / \mathrm{kg}$ ) were found and dosed in the honeys and honeydews derived from other botanical sources, such as willow [17], cornflower [18], robinia, rape, chestnut, clover, linden blossom, dandelion, sunflower, and fir [19]. 
Table 1. The compounds identified by targeted HPLC-DAD analysis of the native honey samples.

\begin{tabular}{|c|c|c|c|c|c|}
\hline \multirow{2}{*}{ No. } & \multirow{2}{*}{ Compound } & \multicolumn{4}{|c|}{ Content (mg/kg) } \\
\hline & & Min. $^{a}$ & Max. ${ }^{b}$ & Av. ${ }^{c}$ & SD. ${ }^{d}$ \\
\hline 1 & Kojic acid & 11.7 & 15.4 & 13.7 & 1.2 \\
\hline 2 & Tyrosine & 17.2 & 59.0 & 35.6 & 14.8 \\
\hline 3 & Phenylalanine & 330.3 & 52.6 & 167.8 & 80.8 \\
\hline 4 & 4-Hydroxyphenylacetic acid & $\mathrm{Nd}^{\mathrm{e}}$ & 36.1 & 21.3 & 8.1 \\
\hline 5 & Benzoic acid & 14.7 & 48.7 & 36.4 & 10.5 \\
\hline 6 & Methyl syringate & 92.1 & 144.4 & 114.1 & 17.8 \\
\hline
\end{tabular}

Besides leptosin, MSYR was identified as the active compound from manuka honey to which its myeloperoxidase (MPO)-activity inhibition is ascribed [20]. MSYR displays the scavenging activity of superoxides and inhibitory effects on aflatoxin production [21,22]. It is also a selective agonist [23,24] of transient receptor potential channel ankryn 1 (TRPA1), and an efficient phenolic mediator for bacterial and fungal laccases [25].

Two aromatic acids, benzoic acid (36.4 $\pm 10.5 \mathrm{mg} / \mathrm{kg})$ and 4-hydroyphenylacetic acid $(21.3 \pm 8.1 \mathrm{mg} / \mathrm{kg})$, as well as kojic acid (5-hydroxy-2-(hydroxymethyl)-4H-pyran-4-one; $13.7 \pm 1.2 \mathrm{mg} / \mathrm{kg}$ ), were also identified in the samples, but in lower concentrations. Partial qualitative similarity with manuka honey is again noticed. Namely, three chemotypes of Leptospermum scoparium honey were identified [20] containing: (i) high levels of 4-hydroxybenzoic acid, dehydrovomifoliol, and benzoic acid; (ii) high concentrations of kojic acid and 2-methoxybenzoic acid and (iii) high contents of syringic acid, 4-methoxyphenyllactic acid, and MSYR. Kojic acid was also detected and dosed [4] by HPLC-DAD in Coffea spp. honey. 4-Hydroxyphenylacetic acid is involved in the scavenging reactive oxygen and nitrogen species, both in vitro and in vivo, with lower potential in comparison with other more hydroxylated aromatic acids [26,27]. Its antioxidant properties were expressed as the ability to scavenge the free radical ABTS $+\left(\mathrm{IC}_{50}(\mu \mathrm{M})=852.713\right)$ and as TEAC (Trolox equivalent antioxidant capacity, $0.030(\mu \mathrm{M})$ ). Kojic acid inhibits catecholase activity of tyrosinase [28]. It is a weak bacterial antagonist, its range of activity being in a dilution of 1:1.000 to 2.000 against the common test bacteria. The MIC (minimum inhibitory concentration) of kojic acid against the human pathogenic fungi was in the range $80-640 \mu \mathrm{g} / \mathrm{mL}$.

Other detected and dosed aromatic acids in the samples were amino acids phenylalanine $(167.8 \pm 80.8 \mathrm{mg} / \mathrm{kg})$ and tyrosine $(35.6 \pm 14.8 \mathrm{mg} / \mathrm{kg})$. The amounts of these amino acids found in one sample of S. hortensis L. were [14]: phenylalanine $282.0 \mathrm{mg} / \mathrm{kg}$ and tyrosine $140.4 \mathrm{mg} / \mathrm{kg}$; there is no data of their distribution in S. montana L. honey. The tyrosine amount was similar to eucalyptus honey $(30.48 \mathrm{mg} / \mathrm{kg})$ and orange blossom honey $(31.5 \mathrm{mg} / \mathrm{kg})$, while phenylalanine content was close to eucalyptus honey $(107 \mathrm{mg} / \mathrm{kg})$ and orange blossom honey $(150 \mathrm{mg} / \mathrm{kg})$, as previously reported [29]. In general, proteins and amino acids in the honey are attributable to animal and vegetal sources, the major of these being pollen [29]. The major amino acids found in rosemary, eucalyptus, lavender, thyme, and orange blossom honeys were proline (the major contributor), phenylalanine, tyrosine, and lysine.

\subsection{GC-FID/MS Analysis of the Ultrasonic Solvent Extracts}

Two solvents were used for the ultrasonic solvent extraction of S. subspicata Vis. honey samples in order to obtain more detailed chemical profiles of the volatile/semi-volatile compounds. The solvents differ in polarity, and consequently could influence the extraction of the compounds according to their polarity and water-solubility. The extracts were analysed by GC-FID/MS, and the results are presented in Table 2. However, the extracts, regardless of the solvent used, were qualitatively very similar, with smaller qualitative differences among minor compounds. The major identified compound was MSYR (46.68\%; 52.98\%), followed by syringaldehyde $(7.30 \% ; 8.80 \%)$, and benzoic 
acid $(2.22 \% ; 1.76 \%)$. Other structurally related compounds were found with minor ranges (Table 2) such as: 3,4,5-trimethylphenol, eugenol, methyl 4-methoxybenzoate, 3,4,5-trimethoxybenzaldehyde, methyl 3,4,5-trimethoxybenzoate, 3,5-dimethoxy-4-hydroxybenzyl alcohol, 3,4,5-trimethoxybenzoic acid, and syringic acid. Significant composition similarity is noticed with the ultrasonic solvent extracts from S. montana L. honey samples [13], with predominant benzene derivatives also leading by MSYR $(53.77 \% \pm 14.59 \%)$, and followed by syringaldehyde $(18.93 \% \pm 18.86 \%)$ and benzoic acid $(5.61 \% \pm 3.60 \%)$. MSYR also predominated $(54.7 \%)$ in the extract of $S$. hortensis L. honey [14], followed by benzoic acid $(2.4 \%)$. Syringic acid was present with lower abundance $(0.72 \% ; 1.15 \%)$, but it was previously found in the plant [12].

Table 2. The compounds identified by GC-FID/MS analysis of the honey extracts.

\begin{tabular}{|c|c|c|c|c|c|c|c|c|c|}
\hline \multirow{2}{*}{ Compound } & \multirow{2}{*}{$\mathbf{R I}^{\mathrm{a}}$} & \multicolumn{4}{|c|}{$I^{b}$} & \multicolumn{4}{|c|}{ II $^{c}$} \\
\hline & & Min. $^{d}$ & Max. ${ }^{\mathrm{e}}$ & Av. ${ }^{f}$ & SD. $\mathrm{g}$ & Min. $^{d}$ & Max. $^{e}$ & Av. ${ }^{f}$ & SD. $\mathrm{g}$ \\
\hline 1,4-Dimethylbenzene ${ }^{* *}$ & $<900$ & 0.0 & 0.3 & 0.14 & 0.11 & 0.0 & 0.1 & 0.06 & 0.06 \\
\hline 1,3-Dimethylbenzene ** & $<900$ & 0.0 & 0.2 & 0.08 & 0.08 & - & - & - & - \\
\hline Decane & 1000 & 0.0 & 0.1 & 0.04 & 0.06 & - & - & - & - \\
\hline Benzoic acid & 1162 & 0.5 & 4.7 & 2.22 & 2.21 & 0.5 & 4.3 & 1.76 & 1.40 \\
\hline 2,4-Dimethylbenzaldehyde ${ }^{* *}$ & 1178 & - & - & - & - & 0.0 & 0.1 & 0.04 & 0.05 \\
\hline 3,7-Dimethylocta-1,5-dien-3,7-diol & 1191 & - & - & - & - & 0.0 & 0.1 & 0.06 & 0.06 \\
\hline 3,4,5-Trimethylphenol ** & 1331 & 0.0 & 0.1 & 0.06 & 0.06 & - & - & - & - \\
\hline Eugenol & 1360 & 0.0 & 0.1 & 0.06 & 0.06 & 0.0 & 0.9 & 0.34 & 0.34 \\
\hline Tetradecane & 1400 & 0.0 & 0.1 & 0.06 & 0.06 & 0.0 & 0.5 & 0.13 & 0.17 \\
\hline$\beta$-Caryophyllene & 1425 & - & - & - & - & 0.0 & 0.1 & 0.04 & 0.05 \\
\hline 4-Methyl-2,6-bis(1,1-dimethylethyl)-phenol & 1520 & 0.2 & 0.5 & 0.31 & 0.13 & 0.0 & 0.6 & 0.16 & 0.24 \\
\hline Methyl 4-methoxybenzoate & 1527 & 0.0 & 1.1 & 0.43 & 0.60 & - & - & - & - \\
\hline Hexadecane & 1600 & 0.0 & 0.6 & 0.18 & 0.27 & 0.0 & 1.3 & 0.42 & 0.48 \\
\hline 3,4,5-Trimethoxybenzaldehyde & 1608 & 000 & 0.4 & 0.14 & 0.19 & 0.0 & 0.7 & 0.20 & 0.31 \\
\hline Syringaldehyde & 1662 & 2.1 & 11.1 & 7.30 & 3.96 & 4.0 & 14.1 & 8.80 & 3.27 \\
\hline Methyl 3,4,5-trimethoxybenzoate * & 1675 & 0.0 & 4.1 & 0.94 & 1.78 & 0.0 & 0.5 & 0.22 & 0.24 \\
\hline 3,5-Dimethoxy-4-hydroxybenzyl alcohol * & 1721 & - & - & - & - & 0.0 & 1.8 & 0.73 & 0.88 \\
\hline Methyl syringate & 1744 & 32.3 & 56.1 & 46.68 & 10.82 & 41.7 & 60.1 & 52.98 & 7.66 \\
\hline 3,4,5-Trimethoxybenzoic acid $* *$ & 1775 & 0.0 & 1.2 & 0.34 & 0.53 & 0.0 & 2.9 & 0.88 & 1.18 \\
\hline Syringic acid & 1840 & 0.0 & 1.4 & 0.72 & 1.02 & 0.0 & 4.1 & 1.15 & 1.63 \\
\hline Hexadecan-1-ol & 1882 & 2.8 & 9.4 & 5.86 & 2.70 & 0.6 & 5.6 & 3.28 & 1.66 \\
\hline Hexadecanoic acid & 1963 & 1.0 & 9.4 & 3.94 & 3.35 & 1.0 & 12.7 & 3.69 & 4.14 \\
\hline Eicosane & 2000 & - & - & - & - & 0.0 & 1.3 & 0.32 & 0.54 \\
\hline Octadecanal & 2024 & - & - & - & - & 0.0 & 1.0 & 0.35 & 0.43 \\
\hline (Z)-Octadec-9-en-1-ol & 2073 & 6.7 & 27.7 & 14.27 & 9.33 & 5.9 & 18.6 & 10.82 & 4.41 \\
\hline Octadecan-1-ol & 2084 & 2.4 & 10.4 & 5.92 & 2.97 & 2.1 & 6.9 & 4.42 & 1.57 \\
\hline Heneicosane & 2100 & 0.0 & 4.0 & 0.12 & 0.18 & 0.0 & 5.5 & 1.40 & 2.11 \\
\hline Octadecanoic acid & 2178 & 0.0 & 0.9 & 0.22 & 0.36 & 0.0 & 1.0 & 0.23 & 0.41 \\
\hline (Z)-Octadec-9-enoic acid & 2181 & - & - & - & - & 0.0 & 0.9 & 0.22 & 0.36 \\
\hline Docosane & 2200 & - & - & - & - & 0.0 & 0.7 & 0.23 & 0.29 \\
\hline Tricosane & 2300 & - & - & - & - & 0.0 & 0.9 & 0.27 & 0.36 \\
\hline
\end{tabular}

${ }^{a}$ retention indices relative to $\mathrm{C}_{9}-\mathrm{C}_{25} n$-alkanes, ${ }^{\mathrm{b}}$ ultrasonic extracts with the solvent pentane/ $\mathrm{Et}_{2} \mathrm{O}$ 1:2 (v/v);

${ }^{\mathrm{c}}$ ultrasonic solvent extract with $\mathrm{CH}_{2} \mathrm{Cl}_{2} ;{ }^{\mathrm{d}}$ minimal percentage; ${ }^{\mathrm{e}}$ maximal percentage; ${ }^{\mathrm{f}}$ average percentage;

$\mathrm{g}$ standard deviation; ${ }^{* *}$ correct isomer is not determined; ${ }^{*}$ tentatively identified.

Higher aliphatic alcohols were another group of abundant compounds in the extracts dominated by (Z)-octadec-9-en-1-ol (14.27\%; 10.82\%), octadecan-1-ol (5.92\%; $4.42 \%)$, and hexadecan-1-ol (5.86\%; $3.28 \%)$, followed by hexadecanoic acid $(3.94 \% ; 3.69 \%)$. These compounds are not important for the honey characterisation since they probably derive from the comb environment [30]. There were no similarities with the plant volatiles (mainly mono- and sesquiterpenes) investigated previously [9].

\subsection{Color, Total Phenolic Content and Antioxidant Properties}

Determined CIE Lab color coordinates, total phenolics, and antioxidant properties of S. subspicata Vis. honey samples determined by UV/VIS spectroscopy are presented in Table 3 . The color is one of the important attribute for honey classification and the evaluation of its quality and authenticity. According to determined lightness value $\left(\mathrm{L}^{*}\right)$, S. subspicata Vis. honey can be classified as a light honey with a medium-high value of $L^{*}(71.8)$. Very similar $L^{*}$ values were found for Eucalyptus and 
Salix spp. honeys [5,31], but with higher values of $\mathrm{a}^{*}, \mathrm{~b}^{*}$, and $\mathrm{C}_{\mathrm{ab}}{ }^{*}$. The honeys with the highest $\mathrm{b}^{*}$ values were found to be sweet chestnut, strawberry-tree, savory, mint, and buckwheat [31]. The color of S. subspicata Vis. honey is different from S. hortensis L., previously investigated and described as a dark honey $\left(\mathrm{L}^{*}<55\right)[14]$.

Table 3. The characteristics of S. subspicata Vis. honey samples.

\begin{tabular}{|c|c|c|c|c|c|c|c|c|}
\hline & \multicolumn{5}{|c|}{ CIE Lab Colour Coordinates } & \multirow{2}{*}{$\begin{array}{c}\text { TP }^{\mathrm{f}} \\
\text { (mg GAE/kg) }\end{array}$} & \multirow{2}{*}{$\begin{array}{c}\text { FRAP g } \\
\left(\mathrm{mmol} \mathrm{Fe}^{2+} / \mathrm{kg}\right)\end{array}$} & \multirow{2}{*}{$\begin{array}{c}\text { DPPH }^{\mathrm{h}} \\
(\mathrm{mmol} \mathrm{TEAC/kg)}\end{array}$} \\
\hline & $L^{* a}$ & $a^{*} \mathbf{b}$ & $b^{* c}$ & $C^{*}{ }_{a b}^{d}$ & $\mathbf{h}^{\circ}{ }_{\mathrm{ab}} \mathrm{e}$ & & & \\
\hline Min. ${ }^{i}$ & 67.0 & 10.7 & 65.7 & 66.6 & 79.0 & 347.14 & 2.93 & 0.57 \\
\hline Max. j & 76.2 & 14.5 & 74.8 & 76.2 & 81.2 & 490.04 & 6.01 & 1.18 \\
\hline Av. ${ }^{k}$ & 71.8 & 12.5 & 71.6 & 72.6 & 80.1 & 425.38 & 4.26 & 0.80 \\
\hline SD. ${ }^{1}$ & 3.1 & 1.4 & 2.9 & 3.0 & 0.8 & 44.20 & 0.90 & 0.19 \\
\hline
\end{tabular}

${ }^{a}$ lightness. ${ }^{b}$ indicates red for positive value and green for negative value; ${ }^{\mathrm{c}}$ indicates yellow for positive value and blue for negative value; ${ }^{\mathrm{d}}$ chroma.; ${ }^{\mathrm{e}}$ hue, deg.; ${ }^{\mathrm{f}}$ Total phenols (TP) value is expressed as gallic acid equivalent (GAE); ${ }^{g}$ FRAP value expressed as millimolar concentration of $\mathrm{Fe}^{2+}$ obtained from a dilution of $\mathrm{FeSO}_{4}$ having an equivalent antioxidant capacity as the honey solution; ${ }^{\mathrm{h}}$ DPPH value expressed as millimolar concentration of TEAC obtained from a dilution of Trolox having an equivalent antiradical capacity as the honey solution; ${ }^{\mathrm{i}}$ minimum value; ${ }^{\mathrm{j}}$ maximum value; ${ }^{\mathrm{k}}$ average value; ${ }^{1}$ standard deviation.

The total phenolic content determined in S. subspicata Vis. honey was $425.38 \mathrm{mg}$ GAE $/ \mathrm{kg}$, while average values for FRAP and DPPH assays were $4.26 \mathrm{mmol} \mathrm{Fe}{ }^{2+} / \mathrm{kg}$ and $0.8 \mathrm{mmol} \mathrm{TEAC} / \mathrm{kg}$, respectively. Similar values were found for $S$. montana L. honey $(382.3 \pm 63.7 \mathrm{mg} \mathrm{GAE} / \mathrm{kg}$, $3.5 \pm 1.0 \mathrm{mmol} \mathrm{Fe}{ }^{2+} / \mathrm{kg}$ and $0.7 \pm 0.2 \mathrm{mmol} \mathrm{TEAC} / \mathrm{kg}$ ). A strong correlation between the antioxidant activity of the honeys and their total phenolic content was previously found [32]. Similar phenolic content $(406.23 \pm 17.22 \mathrm{mg} / \mathrm{kg}$ ) was found in Echium vulgare L. honey [33]. The antioxidant capacity of S. subspicata Vis. honey is several times higher than found for some bright unifloral honeys such as black locust, goldenrod, rapeseed, and lime [34]. Furthermore, S. subspicata Vis. honey showed similar or higher antioxidant activity than several honeys with higher phenolic content, such as Coffea spp., Salix spp., and S. hortensis L. honeys [4,5,14].

Literature data about the antioxidant activity of the honey volatile compounds is limited. As far as we know, besides our previous research $[35,36]$ there are no reports on the antioxidant activity of Croatian honey ultrasonic solvent extracts. The GC-FID/MS analyses of the extracts showed that they were qualitatively very similar with small amounts, and therefore they were combined according to the type of solvent representing EX1 and EX2 (as described in Section 3.3.4.) for DPPH and FRAP assays. The radical scavenging activity of EX1 and EX2 was expressed as the percentage reduction of DPPH radical. The higher DPPH radical percentage reduction of the sample reveals higher radical scavenging (antiradical) activity. The results of EX1 and EX2 radical scavenging activity are shown in Figure 1 as the function of the extracts concentrations.
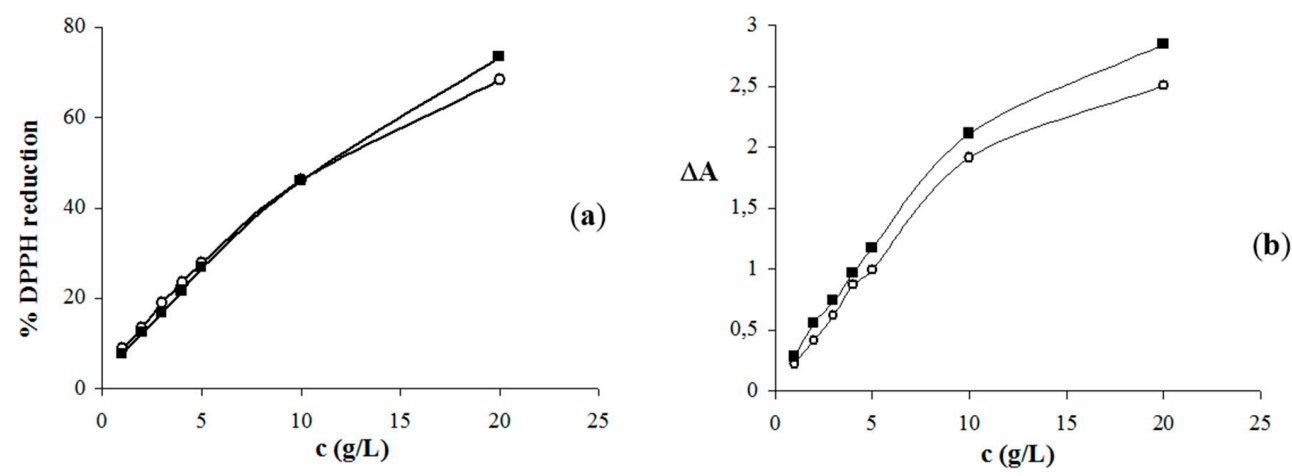

Figure 1. The antiradical activity (a) and reducing potential (b) of S. subspicata Vis. honey extracts: EX1 (○) and EX2 (ם). 
For comparison of antioxidant activity of the honey and its extracts, the average honey sample was prepared (as described in Section 3.3.4.) and tested too. The least active, at a level of only $16.5 \%$, was the average honey sample ( $5 \%$ solution). Considering various modifications of the DPPH method employed by different authors, it is difficult to make direct comparisons of radical scavenging activities of $S$. subspicata Vis. honey with published data. A simple glance at Figure 1 shows that there were no significant differences among the radical scavenging ability of the extracts, although EX2 exhibited slightly better scavenging potential at the highest concentration tested. The antiradical activity of the highest concentration of EX2 $(20.0 \mathrm{~g} / \mathrm{L})$ was $73.4 \%$, in comparison with $68.3 \%$ for the same concentration of EX1. These measurements showed that both honey extracts demonstrated significantly higher antiradical activity than the honey sample at approximately 2.5 times lower concentration (the extracts concentration $20.0 \mathrm{~g} / \mathrm{L}$ vs. the honey solution concentration $50 \mathrm{~g} / \mathrm{L}$ ). The radical scavenging activity is usually expressed as $\mathrm{IC}_{50}$, the concentration of the antioxidant that causes $50 \%$ inhibition of DPPH. $\mathrm{IC}_{50}$ value was approximately determined graphically from Figure 1 , and for both extracts was the same $11.15 \mathrm{~g} / \mathrm{L}$. The average honey sample exhibited a FRAP value of $307.55 \mu \mathrm{M}$ Fe(II) for 5\% honey solution. Same as indicated for antiradical activity, at five times lower concentration both honey extracts demonstrated significantly higher reducing ability than the honey sample. FRAP values of 1\% (10 g/L) EX1 and EX2 solutions were considerably higher: $1909.68 \mu \mathrm{M}$ $\mathrm{Fe}(\mathrm{II})$ for EX1 and $2100.39 \mu \mathrm{M}$ Fe(II) for EX2. Figure 1 shows the concentration-response curves for the solutions of EX1 and EX2. Similar as indicated for the antiradical activity, there were no marked differences between the extracts. The slightly more active was EX2: the reducing capacity expressed as the change in absorbance $(\Delta \mathrm{A})$ between the absorbance reading after $10 \mathrm{~min}$ and reagent blank reading for the highest tested concentration $(20 \mathrm{~g} / \mathrm{L})$ was $2.846 \mathrm{~nm}$, compared to $2.507 \mathrm{~nm}$ for the same concentration of EX1. The reasons behind the observed slight differences in antioxidant activity among the extracts probably arise from their similar chemical composition. The major phenolic compounds found in these extracts were MSYR and syringaldehyde; they were only slightly more abundant in the $\mathrm{CH}_{2} \mathrm{Cl}_{2}$ extract (EX2). Knowing that MSYR exhibited rather low antioxidant activity [15], somewhat higher antioxidant activity of EX2 than EX1 cannot be ascribed to MSYR, but probably to the combined activity of various, even minor, compounds present in the extracts.

\section{Experimental Section}

Ten samples of Satureja subspicata Vis. honey were obtained from professional bee-keepers in Croatia (the bee specie was Apis mellifera carnica). The honey type confirmation was carried out according to the Harmonized methods of melissopalynology [37].

\subsection{HPLC-DAD Analysis}

The honey samples were diluted in ultrapure water 1:10 $(w / v)$, vortexed, and filtered through an RC membrane syringe filter $(0.45 \mu \mathrm{m}, \varnothing 15 \mathrm{~mm}$, Phenex, Torrance, CA, USA) prior to the analysis. The analyses were performed using a HPLC-DAD Varian system ProStar fitted with a pump module 230, an autosampler module 410, and ThermoSeparation diode array detector SpectroSystem UV $6000 \mathrm{lp}$ (ThermoSeparation, San Jose, CA, USA) set at 210 and $280 \mathrm{~nm}$. The gradient elution was performed on Phenomenex Gemini C18 $110 \AA$ A column $(150 \mathrm{~mm} \times 4.60 \mathrm{~mm}, 3 \mu \mathrm{m}$, Chemtek Analitica, Anzola Emilia, Bologna, Italy) using 0.2 M phosphoric acid (solvent A) and acetonitrile (solvent B) as mobile phase. The gradient $(v / v)$ was formed as follows: $100 \%$ of solvent A for 5 min, then decreasing to $20 \%$ in $35 \mathrm{~min}$, and finally increasing to $100 \%$ of solvent B until $60 \mathrm{~min}$. The injection volume was $10 \mu \mathrm{L}$. The obtained chromatograms and spectra were elaborated with a ChromQuest V. 4.0 data system (ThermoQuest, Rodano, Milan, Italy). The standard solutions were prepared in methanol (kojic acid, benzoic acid, 4-hydroxyphenylacetic acid, and methyl syringate) or $0.1 \mathrm{M} \mathrm{HCl} / \mathrm{MeOH} \mathrm{50:50}$ $(v / v)$ (tyrosine and phenylalanine), and working standard solutions were prepared in ultrapure water. The calibration curves were plotted according to the external standard method, correlating the analyte peak areas with the corresponding concentrations. 


\subsection{Ultrasonic Solvent Extraction and GC-FID/MS Analysis of the Extracts}

Ultrasonic solvent extraction (USE) of the honey samples was performed in an ultrasonic bath (Clean 01, MRC Scientific Instruments, London, UK) by indirect sonication at the frequency of $35 \mathrm{kHz}$ and at $25 \pm 3{ }^{\circ} \mathrm{C}$, as described in detail previously [38]. The mixture pentane/Et $\mathrm{O}_{2} 1: 2(\mathrm{v} / \mathrm{v})$ and $\mathrm{CH}_{2} \mathrm{Cl}_{2}$ were separately used as the solvents for the honey extraction (40 g). The obtained extracts were concentrated up to $0.2 \mathrm{~mL}$ by careful distillation with a Danish-Kuderna apparatus, and $1 \mu \mathrm{L}$ of each was used for GC-FID/MS analyses.

GC-FID analyses were carried out on an Agilent Technologies (Palo Alto, CA, USA) gas chromatograph model 7890A with flame ionization detector. The chromatographic separations were performed on $30 \mathrm{~m}$ capillary column HP-5MS (5\%-phenyl-methylpolysiloxane, Agilent J \& W GC column) with $0.25 \mathrm{~mm}$ i.d. and $0.25 \mu \mathrm{m}$ coating thickness. The GC conditions were: $1 \mu \mathrm{L}$ of injected volume with split ratio 1:50; oven programmed at $70{ }^{\circ} \mathrm{C}$ for $2 \mathrm{~min}$, then increased at the rate of $3{ }^{\circ} \mathrm{C} / \mathrm{min}$ to $200{ }^{\circ} \mathrm{C}$ and held isothermal for $15 \mathrm{~min}$; injector temp. $250^{\circ} \mathrm{C}$; detector temp. $300{ }^{\circ} \mathrm{C}$; He carrier gas velocity $1 \mathrm{~mL} / \mathrm{min}$. The GC-MS analyses were performed with an Agilent gas chromatograph model 7890A fitted with mass-selective detector model 5975C (Agilent Technologies). The mass detector conditions were set up as follows: the ion source temperature $230{ }^{\circ} \mathrm{C}$; quadrupole temperature $150{ }^{\circ} \mathrm{C}$; transfer line temperature $270{ }^{\circ} \mathrm{C}$; acquisition mode electron impact (EI $70 \mathrm{eV}$ ) by three scans. $\mathrm{s}^{-1}$ and mass range $m / z$ 29-350. The separation of the compounds was performed in the same manner as for GC-FID. The individual peaks were identified by comparison of their retention indices (relative to $\mathrm{C}_{9}-\mathrm{C}_{25} n$-alkanes) with those of available authentic samples and literature data [39], and by comparing their mass spectra with Wiley 275 MS library (Wiley, New York, NY, USA) and NIST08 (D-Gaithersburg) database. The percentage composition was calculated from the GC peak areas using the normalization method (without correction factors). All the analyses were performed in duplicate.

\subsection{UV/VIS Analyses}

All analyses (Sections 3.3.1-3.3.4) were performed with a UV/VIS spectrophotometer Varian series Cary 50 Scan (Varian, Leinì, TO, Italy).

\subsubsection{CIE $\mathrm{L}^{*} \mathrm{a}^{*} \mathrm{~b}^{*} \mathrm{C}^{*}{ }_{\mathrm{ab}} \mathrm{h}^{\circ}{ }_{\mathrm{ab}}$ Chromatic Coordinates Determination}

The honey samples, homogenized and transparent, were analysed in duplicate in $10 \mathrm{~mm}$ optical polystyrene cuvettes without any dilution (Kartell 01937). The obtained data were processed using Cary Win UV Colour Application V. 2.00 software [31]. Transmittances in a wave-length interval among 380 and $780 \mathrm{~nm}$ were measured using D65 illuminant with a $10^{\circ}$ observation angle.

\subsubsection{Determination of Total Phenolic Content (Folin-Ciocalteu Assay)}

Total phenolic content was determined spectrophotometrically by modified Folin-Ciocalteu method [15]. In each volumetric flask containing $500 \mu \mathrm{L}$ of Folin-Ciocalteu phenol reagent, $100 \mu \mathrm{L}$ of honey/water solution 1:5 (w/v) was added. After $5 \mathrm{~min}, 3 \mathrm{~mL}$ of $10 \% \mathrm{Na}_{2} \mathrm{CO}_{3}(w / v)$ was added and the mixture was shaken and diluted with $\mathrm{H}_{2} \mathrm{O}$ to the volume of $10 \mathrm{~mL}$. After 90 min of incubation at room temperature, the absorbance was read at $725 \mathrm{~nm}$ in $10 \mathrm{~mm}$ polystyrene cuvette (Kartell 01937) against a blank. The total phenolics content was expressed as $\mathrm{mg} / \mathrm{kg}$ of gallic acid equivalent (GAE) using the calibration curve made of freshly prepared gallic acid standard solutions (10-200 mg/L).

\subsubsection{Honey: Total Antioxidant (FRAP Assay) and Antiradical Activity (DPPH Assay)}

The reduction of ferric 2,4,6-tris(2-pyridyl)-1,3,5-triazine [Fe(III)-TPTZ] was monitored by spectrophotometric measurements of absorbance at $593 \mathrm{~nm}$ [15]. Twenty microlitres of the honey/water solution $(1: 5 w / v)$ was added in $10 \mathrm{~mm}$ polystyrene cuvettes (Kartell 01937) containing $2 \mathrm{~mL}$ of freshly prepared reagent $\left(0.3123 \mathrm{~g} \mathrm{TPTZ}, 0.5406 \mathrm{~g} \mathrm{FeCl}_{3} \cdot 6 \mathrm{H}_{2} \mathrm{O}\right.$ in $100 \mathrm{~mL}$ acetate buffer $\mathrm{pH}$ 3.6). 
Quantitative analysis was done using the external standard method $\left(\mathrm{FeSO}_{4}, 0.1-2 \mathrm{mmol} / \mathrm{L}\right)$, correlating the absorbance $(\lambda=593 \mathrm{~nm})$ with the concentration. The results were expressed as $\mathrm{mmol} / \mathrm{kg}$ of Fe$e^{2+}$.

Fifty microlitres of the honey sample diluted with ultrapure $\mathrm{H}_{2} \mathrm{O}(1: 5 w / v)$ was added in $10 \mathrm{~mm}$ cuvettes (Kartell 01937) with $2 \mathrm{~mL}$ of DPPH solution $(0.04 \mathrm{mmol} / \mathrm{L}$ in $\mathrm{MeOH})$ and mixed. The spectrophotometric readings were carried out at $517 \mathrm{~nm}$ after $60 \mathrm{~min}$ incubation in the dark. The calibration curve in the range of $0.02-1.0 \mathrm{mmol} / \mathrm{L}$ was prepared for Trolox, and data were expressed as Trolox equivalent antioxidant capacity (TEAC, $\mathrm{mmol} / \mathrm{kg}$ ).

\subsubsection{Honey Extracts: Total Antioxidant (FRAP Assay) and Antiradical Activity (DPPH Assay)}

Methanolic stock solutions of EX1 (combined ultrasonic extracts obtained with solvent pentane/ $\mathrm{Et}_{2} \mathrm{O} 1: 2(v / v)$ and EX2 (combined ultrasonic extracts obtained with $\mathrm{CH}_{2} \mathrm{Cl}_{2}$ ) were prepared (the concentrations of stock solutions were 1.0, 2.0, 3.0, 4.0, 5.0, 10.0 and $20.0 \mathrm{~g} / \mathrm{L}$ ). Also, the average honey sample, prepared by mixing an equal quantity of each honey sample, was treated with distilled water $(50 \mathrm{~g} / \mathrm{L})$ and sonicated until a clear solution was obtained.

The antiradical potential (DPPH assay) of EX1, EX2, and average honey sample was measured using the stable DPPH radical, according to the method of Brand-Williams, Cuvelier, and Berset [40] with some modifications made by Kulišić et al. [41]. Briefly, a stock solution $(50 \mu \mathrm{L})$ of the antioxidant was placed in a cuvette containing $1 \mathrm{~mL}$ of $0.04 \mathrm{~g} / \mathrm{L}$ methanolic solution of DPPH. The reaction mixture was mixed and left at room temperature in the dark for $60 \mathrm{~min}$. The decrease in absorbance at $517 \mathrm{~nm}$ was measured against methanol blank. The absorbance of the DPPH radical without antioxidant (control) was also measured. All determinations were performed in duplicate. The radical scavenging activity of the samples was expressed in terms of the percentage inhibition of DPPH radical and was calculated as follows:

$$
\% \text { inhibition }=\left[\left(\mathrm{A}_{\mathrm{C}}-\mathrm{A}_{\mathrm{A}}\right) / \mathrm{A}_{\mathrm{C}}\right] \times 100
$$

where $\mathrm{A}_{\mathrm{C}}$ is the control absorbance, and $\mathrm{A}_{\mathrm{A}}$ is the antioxidant absorbance.

Total antioxidant activity was determined by the original method of Benzie and Strain with several modifications [42]. Working FRAP reagent was prepared by mixing 10 volumes of $0.3 \mathrm{M}$ acetate buffer ( $\mathrm{pH}$ 3.6) with one volume of $10 \mathrm{mM}$ TPTZ (2,4,6-tripyridyl-s-triazine) solution in $40 \mathrm{mM} \mathrm{HCl}$ and with one volume of $20 \mathrm{mM}$ ferric chloride $\left(\mathrm{FeCl}_{3} \cdot 6 \mathrm{H}_{2} \mathrm{O}\right)$. Freshly prepared FRAP reagent was warmed to $37^{\circ} \mathrm{C}$, and the absorbance of the reagent blank was measured at $593 \mathrm{~nm}$. All measurements were performed as follows: $50 \mu \mathrm{L}$ of the sample was added to a cuvette containing $1 \mathrm{~mL}$ of freshly prepared FRAP reagent, and the reaction mixture was mixed and incubated at $37^{\circ} \mathrm{C}$ for $10 \mathrm{~min}$. The absorbance was measured spectrophotometrically at $593 \mathrm{~nm}$. The change in absorbance $(\Delta \mathrm{A})$ between the absorbance reading after $10 \mathrm{~min}$ and reagent blank reading for each antioxidant (the honey solution and each concentration of EX1 and EX2) were calculated. The results are expressed graphically, as dose-response curves for the solutions of EX1 and EX2, and as FRAP value ( $\mu \mathrm{M} \mathrm{Fe(II))}$ of EX1 and EX2 solutions (10.0 g/L or 1\%). The FRAP value determination was performed according to the external standard method. Aqueous standard solutions of $\mathrm{FeSO}_{4} \cdot 7 \mathrm{H}_{2} \mathrm{O}(100-1000 \mu \mathrm{M})$ were used for the calibration curve. All determinations were performed in duplicate.

\section{Conclusions}

Screening of unifloral S. subspicata Vis. honey revealed high content of MSYR identified by HPLC-DAD. GC-FID/MS analysis of the honey extracts additionally confirmed MSYR as a dominant chemical marker of Satureja spp. honey types. However, 3-4 times higher amounts of MSYR can be pointed out for distinguishing S. subspicata Vis. honey from other Satureja spp. honey types. Besides MSYR, other prephenate derivatives were found in lower abundance by HPLC-DAD and GC-FID/MS. Total phenolic content and antioxidant properties of the honey samples were similar to other Satureja spp. honey types. The honey extracts evaluated by FRAP and DPPH assays demonstrated higher activity (at lower concentrations) in comparison with the honey. 
Acknowledgments: This work has been fully supported by the Croatian Science Foundation under the project HRZZ-IP-11-2013-8547 "Research of natural products and flavours: chemical fingerprinting and unlocking the potential“. The work of doctoral student Marina Kranjac has been fully supported by the Croatian Science Foundation.

Author Contributions: I.J., C.I.G.T., A.R., M.Z. and M.K. designed the experiments. M.K., Z.M., M.K., M.Z. and C.I.G.T. performed the experiments. M.K., Z.M., M. Z., C.I.G.T., A.R. and I.J. analyzed the data. All the authors discussed and planned the paper. I.J., C.I.G.T., A.R. and M.K. drafted the manuscript.

Conflicts of Interest: The authors declare no conflict of interest.

\section{References}

1. Kaškonienè, V.; Venskutonis, P.R. Floral markers in honey of various botanical and geographic origins: A review. Compr. Rev. Food Sci. Food Saf. 2010, 9, 620-634. [CrossRef]

2. Cuevas-Glory, L.F.; Pino, J.A.; Santiago, L.S.; Sauri-Duch, E. A review of volatile analytical methods for determining the botanical origin of honey. Food Chem. 2007, 103, 1032-1043. [CrossRef]

3. Jerković, I. Terpenes in honey: Occurrence, origin and their role as chemical biomarkers. RSC Adv. 2014, 4, 31710-31728. [CrossRef]

4. Jerković, I.; Tuberoso, C.I.G.; Kuś, P.M.; Marijanović, Z.; Kranjac, M. Screening of Coffea spp. honey by different methodologies: Theobromine and caffeine as chemical markers. RSC Adv. 2014, 4, 60557-60562. [CrossRef]

5. Kuś, P.M.; Marijanović, Z.; Jerković, I. Headspace compounds from Centaurea cyanus L. honey: The occurrence of 3,4-dihydro-3-oxoedulan. Chem. Nat. Compd. 2013, 49, 961-964. [CrossRef]

6. Jerković, I.; Kranjac, M.; Šuste, M.; Kuś, P.M.; Svečnjak, L. Rhamnus frangula honey: Screening of volatile organic compounds and their composition after short-term heating. Chem. Nat. Compd. 2015, 51, 1174-1177. [CrossRef]

7. Šilić, Č. Monographie der Gattungen Satureja L., Calamimtha Miller, Micromeria Bentham, Acinos Miller und Clinopodium L. In Der Flora Jugoslawiens; Zemaljski muzej BiH: Sarajevo, Yugoslavia, 1979; pp. 24-117.

8. Pedersen, J. Distribution and taxonomic implications of some phenolics in the family Lamiaceae determined by ESR spectroscopy. Biochem. Syst. Ecol. 2000, 28, 229-253. [CrossRef]

9. Bezić, N.; Šamanić, I.; Dunkić, V.; Besendorfer, V.; Puizina, J. Essential oil composition and internal transcribed spacer (ITS) sequence variability of four south-Croatian Satureja species (Lamiaceae). Molecules 2009, 14, 925-938. [CrossRef] [PubMed]

10. Cetojević-Simin, D.; Canadanović-Brunet, J.; Bogdanović, G.; Cetković, G.; Tumbas, V.; Djilas, S. Antioxidative and antiproliferative effects of Satureja montana L. extracts. J. BUON 2004, 9, 443-449. [PubMed]

11. Amanlou, M.; Dadkhah, F.; Salehnia, A.; Farsam, H.; Dehpour, A. An anti-inflammatory and anti-nociceptive effects of hydroalcoholic extract of Satureja khuzistanica Jamzad extract. J. Pharm. Sci. 2005, 8, 102-106.

12. Kremer, D.; Košir, I.J.; Končić, M.Z.; Čerenak, A.; Potočnik, T.; Srečec, S.; Randić, M.; Kosalec, I. Antimicrobial and antioxidant properties of Satureja montana L. and S. subspicata Vis. (Lamiaceae). Curr. Drug Targets 2015, 16, 1623-1633. [CrossRef] [PubMed]

13. Jerković, I.; Tuberoso, C.I.G.; Marijanović, Z.; Kranjac, M.; Malenica-Staver, M. Antioxidant capacity and chemical profiles of Satureja montana L. honey: Hotrienol and syringyl derivatives as biomarkers. Chem. Biodivers. 2015, 12, 1047-1056. [CrossRef] [PubMed]

14. Jerković, I.; Tuberoso, C.I.G.; Baranović, G.; Marijanović, Z.; Kranjac, M.; Svečnjak, L.; Kuś, P.M. Characterization of summer savory (Satureja hortensis L.) honey by physico-chemical parameters and chromatographic/spectroscopic techniques (GC-FID/MS, HPLC-DAD, UV/VIS and FTIR-ATR). Croat. Chem. Acta 2015, 88, 15-22. [CrossRef]

15. Tuberoso, C.I.G.; Bifulco, E.; Jerković, I.; Caboni, P.; Cabras, P.; Floris, I. Methyl syringate: A chemical marker of asphodel (Asphodelus microcarpus Salzm. et Viv.) monofloral honey. J. Agric. Food Chem. 2009, 57, 3895-3900. [CrossRef] [PubMed]

16. Stephens, J.M.; Schlothauer, R.C.; Morris, B.D.; Yang, D.; Fearnley, L.; Greenwood, D.R.; Loomes, K.M. Phenolic composition and methylglyoxal in some New Zealand manuka and kanuka honeys. Food Chem. 2010, 120, 78-86. [CrossRef] 
17. Jerković, I.; Kuś, P.M.; Tuberoso, C.I.G.; Šarolić, M. Phytochemical and physical-chemical analysis of Polish willow (Salix spp.) honey: Identification of the marker compounds. Food Chem. 2014, 145, 8-14. [CrossRef] [PubMed]

18. Kuś, P.M.; Jerković, I.; Tuberoso, C.I.G.; Marijanović, Z.; Congiu, F. Cornflower (Centaurea cyanus L.) honey quality parameters: Chromatographic fingerprints, chemical biomarkers, antioxidant capacity and others. Food Chem. 2014, 142, 12-18. [CrossRef] [PubMed]

19. Joerg, E.; Sontag, G. Multichannel coulometric detection coupled with liquid chromatography for determination of phenolic esters in honey. J. Chromatogr. 1993, 635, 137-142. [CrossRef]

20. Alvarez-Suarez, J.M.; Gasparrini, M.; Forbes-Hernández, T.Y.; Mazzoni, L.; Giampieri, F. The composition and biological activity of honey: A focus on manuka honey. Foods 2014, 3, 420-432. [CrossRef]

21. Inoue, K.; Murayama, S.; Seshimo, F.; Takeba, K.; Yoshimura, Y.; Nakazawa, H. Identification of phenolic compound in manuka honey as specific superoxide anion radical scavenger using electron spin resonance (ESR) and liquid chromatography with coulometric array detection. J. Sci. Food Agric. 2005, 85, 872-878. [CrossRef]

22. Jermnak, U.; Yoshinari, T.; Sugiyama, Y.; Tsuyuki, R.; Nagasawa, H.; Sakuda, S. Isolation of methyl syringate as a specific aflatoxin production inhibitor from the essential oil of Betula alba and aflatoxin production inhibitory activities of its related compounds. Int. J. Food Microbiol. 2012, 153, 339-344. [CrossRef] [PubMed]

23. Kim, M.J.; Son, H.J.; Song, S.H.; Jung, M.; Kim, Y.; Rhyu, M.R. The TRPA1 agonist, methyl syringate suppresses food intake and gastric emptying. PLoS ONE 2013, 8, e71603. [CrossRef] [PubMed]

24. Son, H.J.; Kim, M.J.; Park, J.H.; Ishii, S.; Misaka, T.; Rhyu, M.R. Methyl syringate, a low-molecular-weight phenolic ester, as an activator of the chemosensory ion channel TRPA1. Arch. Pharm. Res. 2012, 35, 2211-2218. [CrossRef] [PubMed]

25. Rosado, T.; Bernardo, P.; Koci, K.; Coelho, A.V.; Robalo, M.P.; Martins, L.O. Methyl syringate: An efficient phenolic mediator for bacterial and fungal laccases. Bioresour. Technol. 2012, 124, 371-378. [CrossRef] [PubMed]

26. Mani, A.R.; Pannala, A.S.; Orie, N.N.; Ollosson, R.; Harry, D.; Rice-Evans, C.A.; Moore, K.P. Nitration of endogenous para-hydroxyphenylacetic acid and the metabolism of nitrotyrosine. Biochem. J. 2003, 374, 521-527. [CrossRef] [PubMed]

27. Takahama, U.; Oniki, T.; Murata, H. The presence of 4-hydroxyphenylacetic acid in human saliva and the possibility of its nitration by salivary nitrite in the stomach. FEBS Lett. 2002, 518, 116-118. [CrossRef]

28. Cabanes, J.; Chazarra, S.; Garcia-Carmona, F. Kojic acid, a cosmetic skin whitening agent, is a slow-binding inhibitor of catecholase activity of tyrosinase. J. Pharm. Pharmacol. 1994, 46, 982-985. [CrossRef] [PubMed]

29. Hermosí, I.; Chicón, R.M.; Dolores Cabezudo, M. Free amino acid composition and botanical origin of honey. Food Chem. 2003, 83, 263-268. [CrossRef]

30. Jerković, I.; Marijanović, Z.; Ljubičić, I.; Gugić, M. Contribution of the bees and combs to honey volatiles: Blank-trial probe for chemical profiling of honey biodiversity. Chem. Biodivers. 2010, 7, 1217-1230. [CrossRef] [PubMed]

31. Tuberoso, C.I.G.; Jerković, I.; Sarais, G.; Congiu, F.; Marijanović, Z.; Kuś, P.M. Color evaluation of seventeen European unifloral honey types by means of spectrophotometrically determined $\mathrm{CIE} \mathrm{L}^{*} \mathrm{Cab}{ }^{*} \mathrm{~h}(\mathrm{ab})^{\circ}$ chromaticity coordinates. Food Chem. 2014, 145, 284-291. [CrossRef] [PubMed]

32. Gheldof, N.; Engeseth, N.J. Antioxidant capacity of honeys from various floral sources based on the determination of oxygen radical absorbance capacity and inhibition of in vitro lipoprotein oxidation in human serum samples. J. Agric. Food Chem. 2002, 50, 3050-3055. [CrossRef] [PubMed]

33. Ferreira, I.C.F.R.; Aires, E.; Barreira, J.C.M.; Estevinho, L.M. Antioxidant activity of Portuguese honey samples: Different contributions of the entire honey and phenolic extract. Food Chem. 2009, 114, 1438-1443. [CrossRef]

34. Kuś, P.M.; Congiu, F.; Teper, D.; Sroka, Z.; Jerković, I.; Tuberoso, C.I.G. Antioxidant activity, color characteristics, total phenol content and general HPLC fingerprints of six Polish unifloral honey types. LWT Food Sci. Technol. 2014, 55, 124-130. [CrossRef]

35. Jerković, I.; Marijanović, Z.; Kezić, J.; Gugić, M. Headspace, volatile and semi-volatile organic compounds diversity and radical scavenging activity of ultrasonic solvent extracts from Amorpha fruticosa honey samples. Molecules 2009, 14, 2717-2728. [CrossRef] [PubMed] 
36. Jerković, I.; Marijanović, Z. Oak (Quercus frainetto Ten.) honeydew honey-Approach to screening of volatile organic composition and antioxidant capacity (DPPH and FRAP assay). Molecules 2010, 15, 3744-3756. [CrossRef] [PubMed]

37. Von der Ohe, W.; Persano Oddo, L.; Piana, M.L.; Morlot, M.; Martin, P. Harmonized methods of melissopalynology. Apidologie 2004, 35, 18-25. [CrossRef]

38. Jerković, I.; Tuberoso, C.I.G.; Kasum, A.; Marijanović, Z. Volatile compounds of Asphodelus microcarpus Salzm. et Viv. honey obtained by HS-SPME and USE analyzed by GC/MS. Chem. Biodivers. 2011, 8, 587-598. [CrossRef] [PubMed]

39. El-Sayed, A.M. The Pherobase: Database of Insect Pheromones and Semiochemicals. Available online: http:/ /www.pherobase.com (accessed on 10 February 2016).

40. Brand-Williams, W.; Cuvelier, M.E.; Berset, C. Use of free radical method to evaluate antioxidant activity. LWT Food Sci. Technol. 1995, 28, 25-30. [CrossRef]

41. Kulisic, T.; Radonic, A.; Katalinic, V.; Milos, M. Use of different methods for testing antioxidative activity of oregano essential oil. Food Chem. 2004, 85, 633-640. [CrossRef]

42. Benzie, I.F.F.; Strain, J.J. The Ferric reducing ability of plasma (FRAP) as a measure of "antioxidant power": The FRAP assay. Anal. Biochem. 1996, 239, 70-76. [CrossRef] [PubMed]

Sample Availability: Samples of the compounds are available from the authors for limited time.

(C) 2016 by the authors; licensee MDPI, Basel, Switzerland. This article is an open access article distributed under the terms and conditions of the Creative Commons by Attribution (CC-BY) license (http://creativecommons.org/licenses/by/4.0/). 